\title{
THE UTILIZATION OF RICE HUSK WITH FURNACE MODIFICATION BASED ON THE HEAT EXCHANGER PIPE TYPE FOR SUSTAINABLE ENERGY OF TRADITIONAL DRYING
}

\section{GEDE BAWA SUSANA \& IDA BAGUS ALIT}

Department of Mechanical Engineering, Mataram University, Jl. Majapahit No. 62, Mataram, NTB, 83125, Indonesia

\begin{abstract}
A sustainable energy source that is cheap and easy to obtain is rice husk biomass. This study therefore aims at evaluating the utilization of rice husk with furnace modification based on heat exchanger pipe for sustainable energy of traditional drying. The utilization is through thermal conversion of biomass using a furnace and heat exchanger. The furnace is a burning medium of biomass that contains heat exchanger pipes. Furnace modification is based on the type of heat exchanger pipe, which includes copper, stainless and black steel. The furnace model contains a wall consisting of 468 holes with a $5 \mathrm{~cm}$ distance between the holes and a diameter of $1 \mathrm{~cm}$. The diameter of the ash hole is $12 \mathrm{~mm}$ and the furnace dimensions are $500 \mathrm{~mm} \times 500 \mathrm{~mm} \times 800 \mathrm{~mm}$ with a heat exchanger pipe of diameter 1 inch. The test results on 4 kg of corn carried out for 400 minutes showed that the rice husk utilization provided the optimal drying temperature. The average drying temperature for copper pipes are $82.47^{\circ} \mathrm{C}$ (shelf 1 ), $77.54^{\circ} \mathrm{C}$ (shelf 2), $69.03^{\circ} \mathrm{C}$ (shelf 3), and $62.49^{\circ} \mathrm{C}$ (shelf 4); for black steel pipe, the average drying temperature are $75.73^{\circ} \mathrm{C}$ (shelf 1 ), $72.98^{\circ} \mathrm{C}$ (shelf 2 ), $62.33^{\circ} \mathrm{C}$ (shelf 3), and $55.96^{\circ} \mathrm{C}$ (shelf 4 ) and that of stainless steel pipes are $71.89^{\circ} \mathrm{C}$ (shelf 1 ), $64.23^{\circ} \mathrm{C}$ (shelf 2 ), $59.91^{\circ} \mathrm{C}$ (shelf 3 ), and $51.69^{\circ} \mathrm{C}$ (shelf 4).

KEYWORDS: Rice Husk, Pipe Type, Heat Exchanger, Traditional Dryer
\end{abstract}

Received: Jul 08, 2020; Accepted: Aug 28, 2020; Published: Sep 09, 2020; Paper Id.: IJMPERDAUG202025

\section{INTRODUCTION}

Sun drying is one of the easiest and cheapest ways of preserving food items to avoid decay and damage. The process possesses several advantages which includes reduction in the cost of cooling and packaging, reduced products decay and deterioration, cheaper storage and transportation and a guaranteed availability of seasonal products [1]. Traditional or sun drying is practiced by most Indonesians, especially Lombok and it involves the use of woven bamboo or plastic tarp. It is carried out on a household scale and the results are sufficient for daily needs.

Drying is carried out in open areas such as fields, roadsides, yards, and houses roofs. The resulting product is not hygienic due to exposure to dust or dirt. This is evident in the drying process of shrimp in the sun which results in a relatively darker texture and lower quality than oven drying [2]. Also, sun drying produces hard and dusty products with poor quality and lacks strong added value [3].

The sun as one of the sustainable energy for drying process traditionally produces less than optimal temperatures. At average, the sun temperature during bright weather is $34.75^{\circ} \mathrm{C}$ and this is traditionally used to dry anchovies [4]. In addition, sun drying can damage the nutritional and sensory properties of a product due to heat sensitivity, such as in fruits and vegetables [5]. Traditional drying degrades product quality because the product structure is damaged. This is evaluated through physical parameters such as texture, volume, porosity, and pore size 
distribution [6]. Furthermore, there is a constraint associated with sun drying, this include cloudy or rainy weather which hinders the drying process of product. Due to this constraint, an alternative source is required.

A sustainable energy resources that is cheap and easy to obtain on Lombok Island is biomass. Many biomass like coconut husks, corn cob, and rice husks are in abundance in this Island. It is utilized for traditional drying through furnace modification with the addition of a heat exchanger. The dryer is designed based on input from the community who conducts food drying businesses on a household scale. This is an application of participatory principle. The biomass are easily obtained around the residence and furnace materials as well as heat exchangers are available at affordable prices in the market.

The sustainable energy utilization for drying through thermal conversion of biomass is implemented through the use of furnaces and heat exchangers. The furnace is a medium for burning biomass and it contains heat exchanger pipes. This pipe is a medium for the drying air that allows the flow of heat transfer from the biomass. The heat exchanger for applies the heat transfer process between two fluids separated by walls and with different temperatures [7]. The cross-flow heat exchanger warms up the drying air with the energy of the firewood biomass and generates the highest temperature of $66.7^{\circ} \mathrm{C}$ in the vacuum room [8]. Also, the heat exchanger that is placed in the furnace impacts changes in drying temperature. The test results in the vacuum drying room showed an average and highest temperature of $72.79^{\circ} \mathrm{C}$ and $109.2^{\circ} \mathrm{C}$ respectively [9]. In addition, the utilization of gas to gas heat exchanger model with solid biomass as an energy source is useful for the drying process of palm fibers [10]. The heat exchanger, which was placed separately from a furnace for burning coconut coir biomass, gave an average drying temperature of $41.30^{\circ} \mathrm{C}$ which is suitable for drying anchovies [4]. The heat exchanger pipes with a triangular arrangement are used in furnace with rice husk as fuel to ensure that the there is no mixture of the air entering the drying chamber with the combustion exhaust gases. This method is used for agricultural engineering standards in the Philippines [11].

Air circulation influences biomass combustion process in the furnace to produce drying hot air. An improved dryer performance is directly proportional to increase holes in furnace wall [12]. The test results on $4 \mathrm{~kg}$ of corn showed that it took 58 minutes to obtain a moisture content of $12 \%$ from initial 19\%. Furthermore, heat exchanger with tube bundle arrangement produces hot air temperature of $55^{\circ} \mathrm{C}$. This model is used for the regeneration process of silica gel obtained by using a tube diameter of 0.375 inches [13]. Furnace and heat exchanger utilization optimize sustainable energy use such as biomass. This is an alternative for days with cloudy or rainy weather to optimize traditional drying in the household business sector. In addition, heat exchangers facilitate the heat transfer process from biomass furnace into the drying chamber.

Biomass is obtained from wood and various types of agricultural waste such as coconut husks, coconut shells, and rice husks. Rice husk biomass as a sustainable energy has high potential to replace fossil energy. Also, it has high electrical power potential, which is processed through the gasification method [14]. Rice husks are estimated to have a total power generation potential of $9.8 \mathrm{GW}$ [15]. Its potential in West Nusa Tenggara region is 533,150.80 tons, while for Lombok island is $269,420.20$ tons and it is estimated to produce enough energy to support a power capacity of 60-65 MW [16, 17]. However, rice husks are considered waste and pollutant for the environment in the rural areas. Its utilization to date is to warm pet animals in a cage and also ad direct combustion for cooking.

The utilization of rice husks for effective and efficient drying is implemented through a thermal conversion process. Also, husk is a byproduct used for energy production with a net calorific value of 12-16 MJ / kg [18]. This 
calorific value is quite high and it is equivalent to half the calorific value of coal which is $12.3 \mathrm{MJ} / \mathrm{kg}$ [19] and 11-15.3 MJ / kg [20]. The test results on rectangular fluidized bed combustor show that rice husk as fuel has flame stabilization, low emissions, and high combustion efficiency reaching 99.2\% [21]. In addition, a downdraft furnace was developed to overcome the uneven temperature on rice drying [22]. Tests were also carried out by boiling two liters of water through direct burning of rice husks and firewood and the result showed a ratio of $1 \mathrm{~kg}$ in 15 minutes and $1.2 \mathrm{~kg}$ in 21 minutes, respectively [23]. Combustion test result of $1 \mathrm{~kg}$ rice husk using a furnace showed that a maximum temperature of $556.5^{\circ} \mathrm{C}$ was reached during complete combustion after 30 minutes [24]. The high production of rice husks on the island possesses the potential of sustainable energy for drying food in order to improve the lives standards of rural communities. By increasing property and logistics factors, rice husks can become a renewable energy source [25].

\section{MATERIALS AND METHODS}

This study uses rice husks as fuel in a furnace due to its abundant production on the Lombok Island. The dryer design uses the most optimal results from research $[9,12]$ by making modifications to the furnace based on the type of heat exchanger pipe. The furnace walls for burning rice husks consist of 468 holes with a distance of $5 \mathrm{~cm}$ and a diameter of $1 \mathrm{~cm}$ [12]. Also, the diameter of an ash hole is $12 \mathrm{~mm}$ [9]. The furnace material is made of iron plates with a length, width and height of $500 \mathrm{~mm}, 500 \mathrm{~mm}$, and $800 \mathrm{~mm}$ respectively. Also, iron material was used because it is affordable, easy to obtain, resistant to the burning heat of rice husks, and the product is easy to work with. In addition, the drying chamber has length, width, and height of $536 \mathrm{~mm}, 536 \mathrm{~mm}$, and $600 \mathrm{~mm}$, respectively from aluminum material and is insulated using $3 \mathrm{~mm}$ rubber. Furthermore, aluminum material is used because it is easy to form and obtain, affordable prices, and good heat conductor. Also, rubber insulators are used to inhibit heat transfer from the drying chamber to the environment. The design of furnace for burning rice husks and drying rooms is as shown in Figure 1
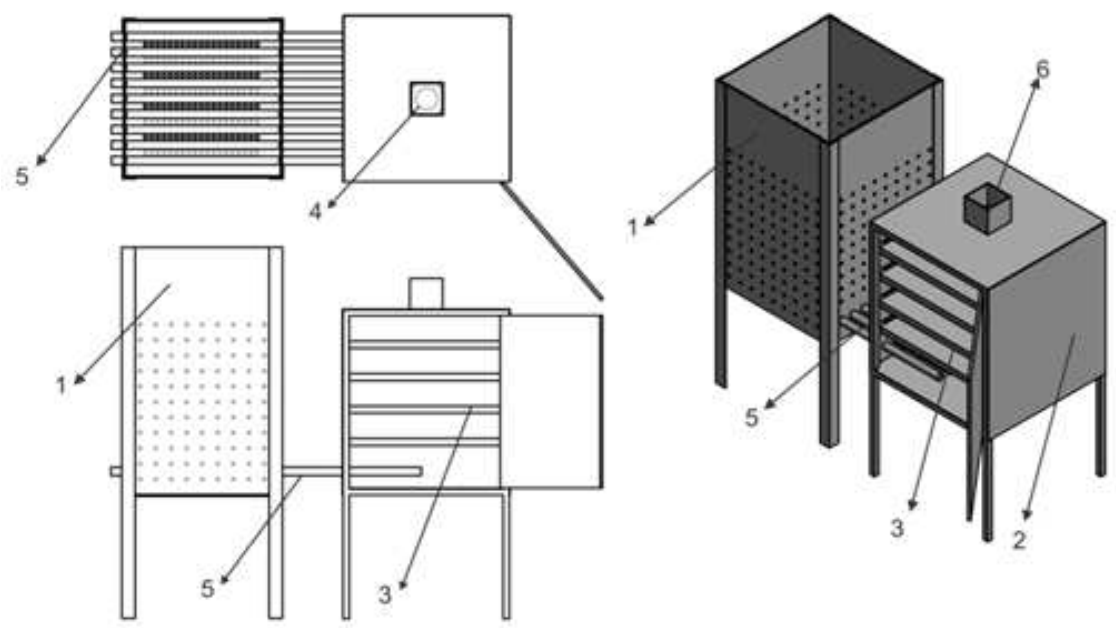

Description:

1. Furnace

2. Drying chamber

3. Drying shelves

4. Exhaust fan

5. Heat exchanger pipe

6. Chimney

Figure 1: Design of a Furnace with Heat Exchanger and Drying Chamber.

The drying test of foodstuff used corn as the sample. Post-harvest handling is a priority to maintain quality as corn is an important nutritional source alongside rice. The $4 \mathrm{~kg}$ corn sample was evenly distributed on 4 shelf inside the drying chamber of each $\mathrm{kg}$. The application of forced convection through the addition of exhaust fan is carried out at the exhaust channel of drying chamber at a constant speed of $2 \mathrm{~m} / \mathrm{s}$. The test method is as shown in Figure 2. 


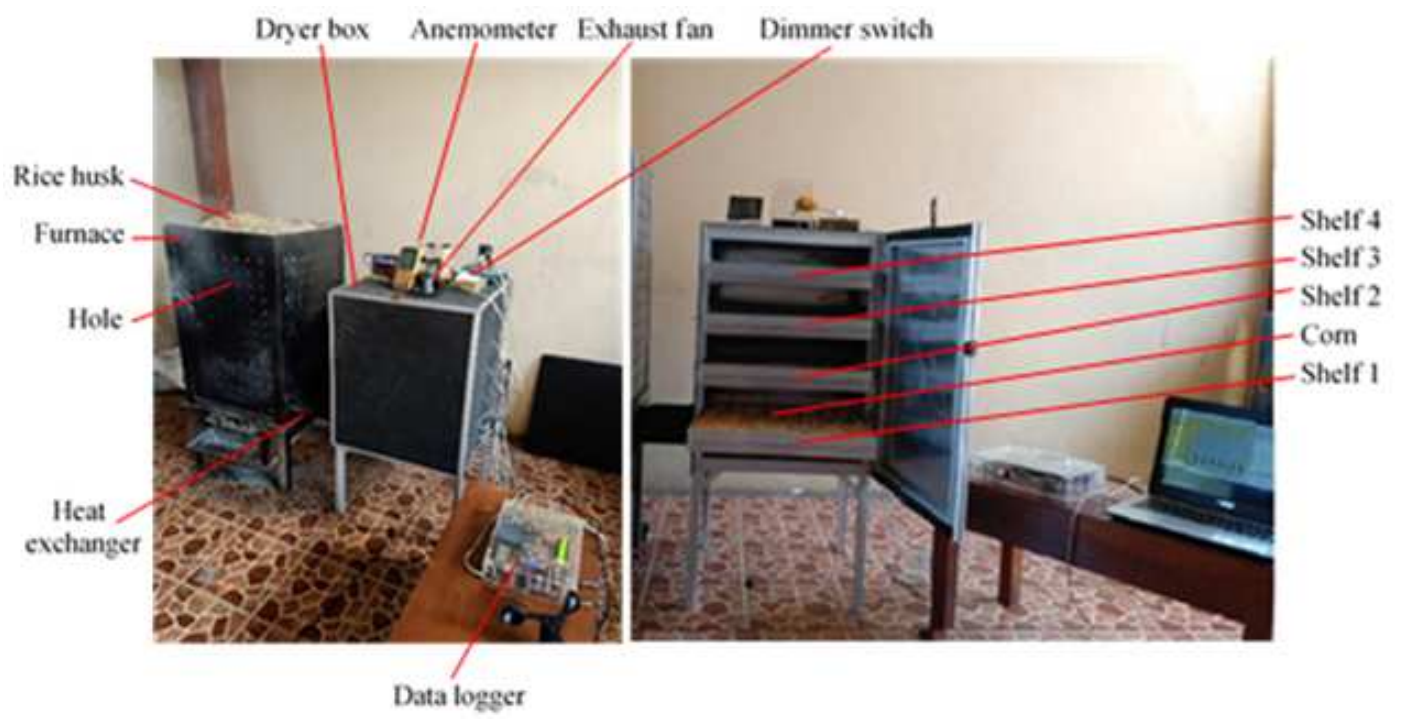

Figure 2: Testing of Corn Samples on Furnace Modification Based on The Type of Heat Exchanger Pipe.

The husks are burned outside the heat exchanger pipes in the furnace. Then the heat from its combustion is transferred to the ambient air that flows in the pipes. The heat exchanger is then placed at the bottom of the furnace consisting of 9 rows of pipes arranged parallel to one airflow path. The pipe length and diameter are $1 \mathrm{~m}$ and 1 inch, respectively. The type of heat exchanger pipe used in this research are copper, stainless, and black steel materials. The design is shown in Figure 3.

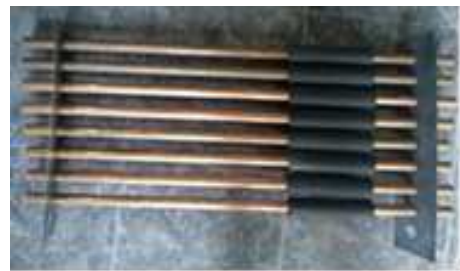

(a)

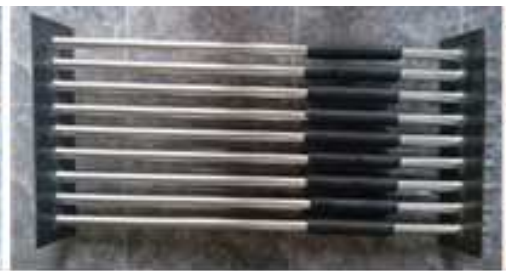

(b)

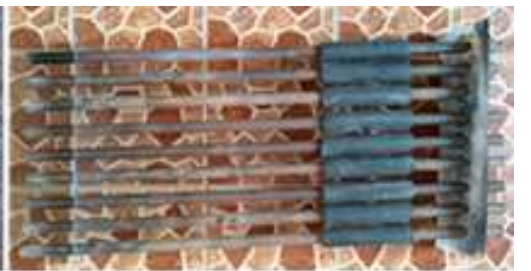

(c)

Figure 3: Types of Heat Exchanger Pipe with Material a) Copper, b) Stainless Steel, and c) Black Steel.

This research implements participatory concept of community involvement as a household business in the drying of foodstuffs. Based on this, tool testing is carried out in accordance with the user's working time ability. The equipment resistance was also tested to dry the food with corn samples within 400 minutes. The type of heat exchanger pipe material is adjusted to people's purchasing power and is easily found on the market.

\section{RESULTS AND DISCUSSIONS}

The furnace is rectangular with air holes in the walls. The combustion results based on testing $20 \mathrm{~kg}$ of rice husk are shown in Figure 4. 

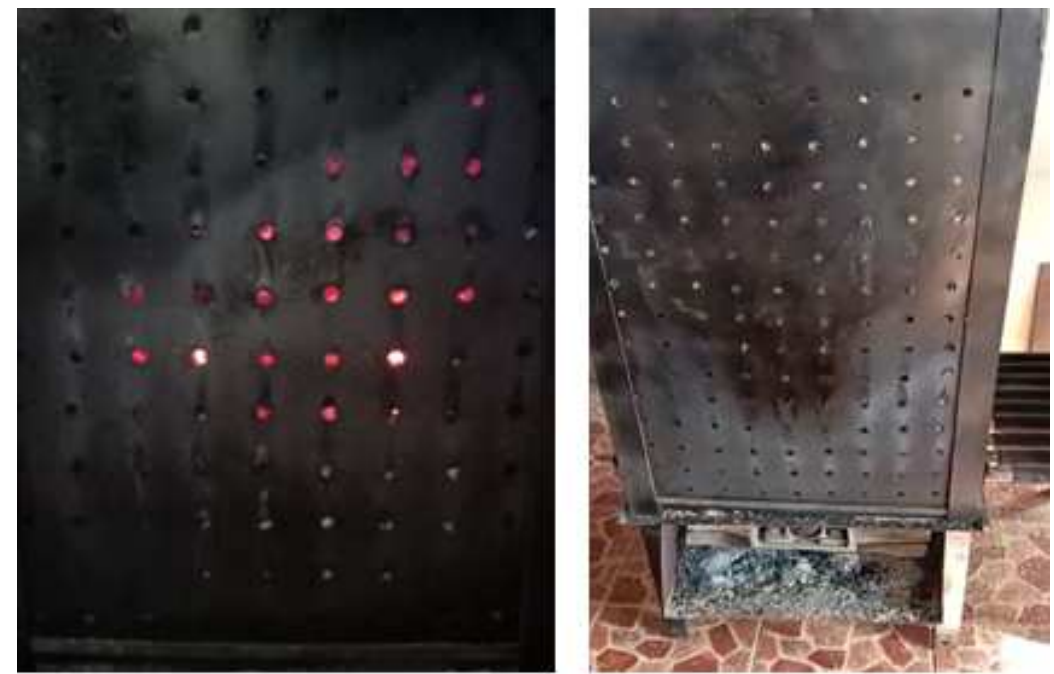

Figure 4: The Process of Rice Husks Combustion in a Furnace Equipped with a Heat Exchanger.

The drying process using rice husk biomass energy shows that the ambient temperature has no significant does not have a significant effect. The average ambient temperature are $28.25^{\circ} \mathrm{C}, 27.99^{\circ} \mathrm{C}$, and $27.45^{\circ} \mathrm{C}$ in the drying process respectively on the use of copper, stainless steel, and black steel pipes. This is shown in Figure 5.

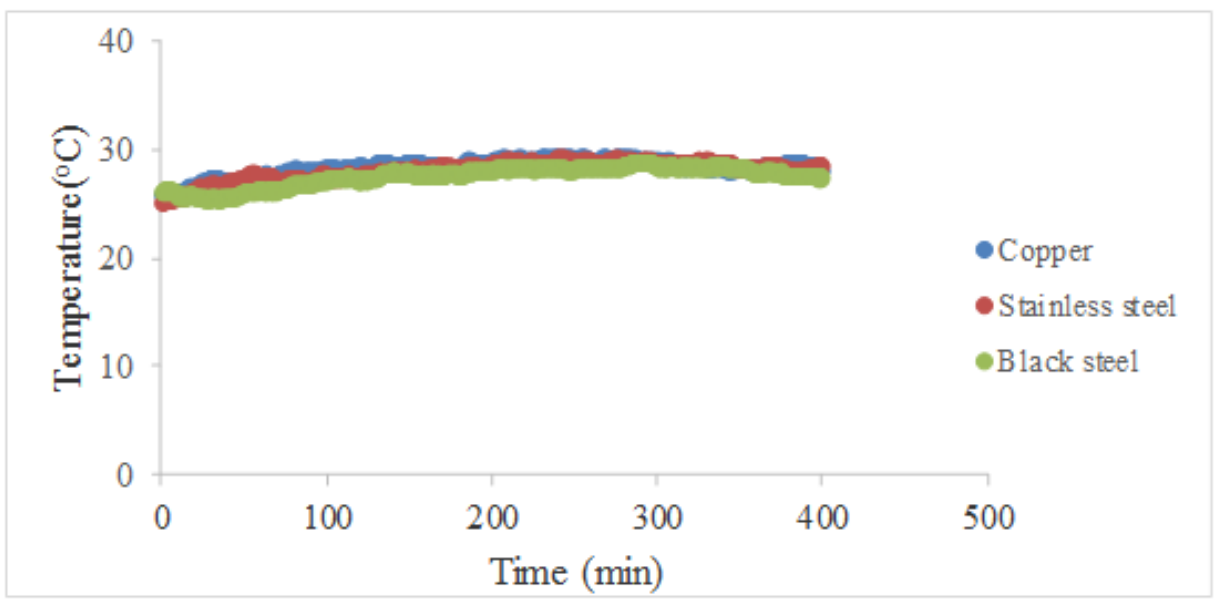

Figure 5: Ambient Temperature Distribution in Various Types of Heat Exchanger Pipes.

Figure 6 shows phenomenon of corn drying temperature using a modified furnace based on the type of heat exchanger pipe. Figure 6a shows the comparison of temperatures on shelf 1 in drying chamber using copper (1-copper), stainless (1-stainless steel), and black steel (1-black steel) pipes. Figure 6b shows the comparison of drying temperatures on shelf 2 using copper (2-copper), stainless steel (2-stainless steel), and black steels (2-black steels) pipes. Figure 6c shows the comparison of drying temperatures on shelf 3 using copper (3-copper), stainless steel (3-stainless steel), and black steels (3-black steels) pipes. Figure 6d shows the comparison of drying temperatures on shelf 4 using copper (4copper), stainless steel (4-stainless steel), and black steels (4-black steels) pipes. The drying temperature distribution has almost the same trend in the three types of heat exchanger pipes. At the beginning of combustion, there was no significant increase in temperature. This shows that the combustion phenomenon begins with the evaporation of rice husk moisture content. However, a significant increase in temperature occurs when the rice husks started turning into charcoal. When it is in charcoal form, the resulting temperature is at its maximum. The biomass drying zone occurs for the evaporation process of moisture content before further heating [26] and rice husks have a moisture content of 10\% [27]. 


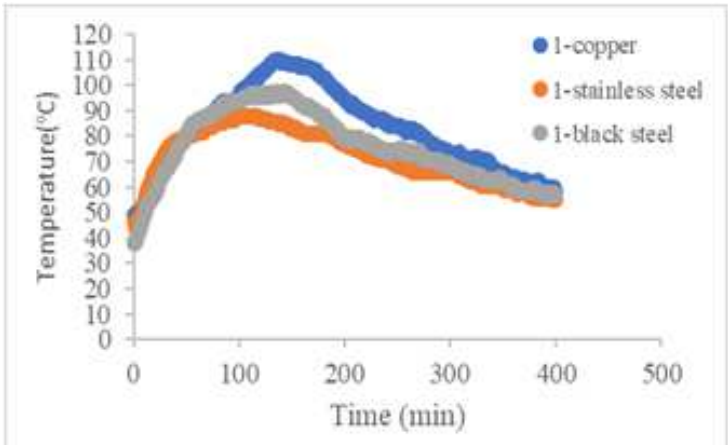

(a)

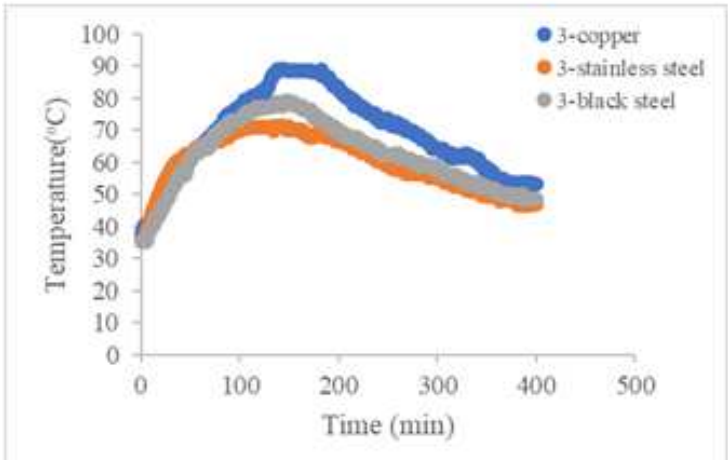

(c)

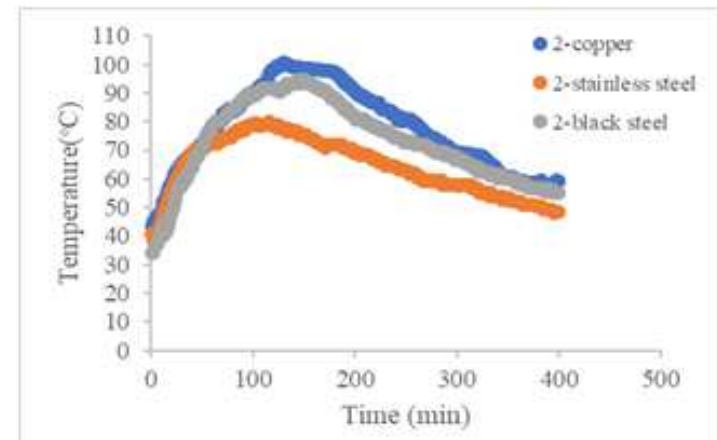

(b)

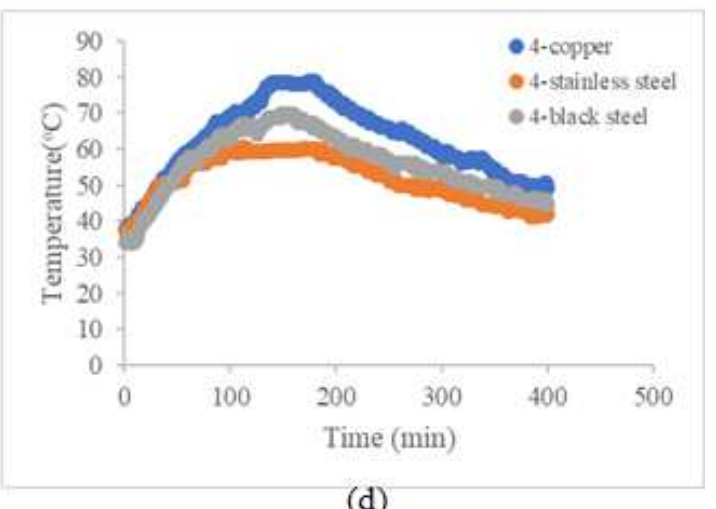

(d)

Figure 6: Distribution of Drying Temperature for Each Shelf in Drying Chamber on the Various Types of Heat Exchanger Pipes.

The highest drying temperature is obtained when using a copper heat exchanger pipe. Also, the highest temperature distribution in copper pipes occurs on each shelf in the drying chamber. In addition, the average drying temperature for copper pipes is $82.47^{\circ} \mathrm{C}$ (shelf 1 ), $77.54^{\circ} \mathrm{C}$ (shelf 2), $69.03^{\circ} \mathrm{C}$ (shelf 3), and $62.49^{\circ} \mathrm{C}$ (shelf 4). The range of drying temperature for copper pipes are $48.28-109.96^{\circ} \mathrm{C}$ (shelf 1), $43.52-100.55^{\circ} \mathrm{C}$ (shelf 2), 37.73-88.95 $\mathrm{C}($ shelf 3 ), and $37.83-78.89^{\circ} \mathrm{C}$ (shelf 4). Also, the average drying temperature of black steel pipes are $75.73^{\circ} \mathrm{C}$ (shelf 1 ), $72.98^{\circ} \mathrm{C}$ (shelf 2 ), $62.33^{\circ} \mathrm{C}$ (shelf 3 ), and $55.96^{\circ} \mathrm{C}$ (shelf 4). Also, for black steels are $37.92-97.35^{\circ} \mathrm{C}$ (shelf 1 ), $33.95-94.74^{\circ} \mathrm{C}$ (shelf 2 ), $35.27-79.14^{\circ} \mathrm{C}$ (shelf 3 ), and $33.85-69.89^{\circ} \mathrm{C}$ (shelf 4). The average drying temperature for stainless steel pipes are $71.89^{\circ} \mathrm{C}$ (shelf 1), $64.23^{\circ} \mathrm{C}$ (shelf 2), $59.91^{\circ} \mathrm{C}$ (shelf 3), and $51.69^{\circ} \mathrm{C}$ (shelf 4). Also, the range of drying temperature for stainless steel pipes are $43.78-88.11^{\circ} \mathrm{C}$ (shelf 1 ), $38.41-80.08^{\circ} \mathrm{C}$ (shelf 2), 35.86-71.47 $7^{\circ} \mathrm{C}$ (shelf 3 ), and $37.09-60.53^{\circ} \mathrm{C}$ (shelf 4 ).

Copper pipes produce the highest drying temperature occurring on shelf 1 compared to the position of shelf 2, 3, and 4. The position of shelf 1 was closest to the heat exchanger pipe output or drying chamber input temperature. Also, the smallest temperature distribution in the drying chamber occurs on shelf 4 . This is caused by the heat that is previously absorbed by the dried corn on the shelf below. Also, the 4 shelf position is away from the heat source. The same condition also occurs in stainless steel pipe and black steel. This is in line with the research [28], that the heating source near the shelf will directly hit the dried product. This provides the highest temperature drying effect.

Figure 7 shows the average distribution of drying temperature in the dryer chamber for the copper, stainless and black steel heat exchanger pipes. 


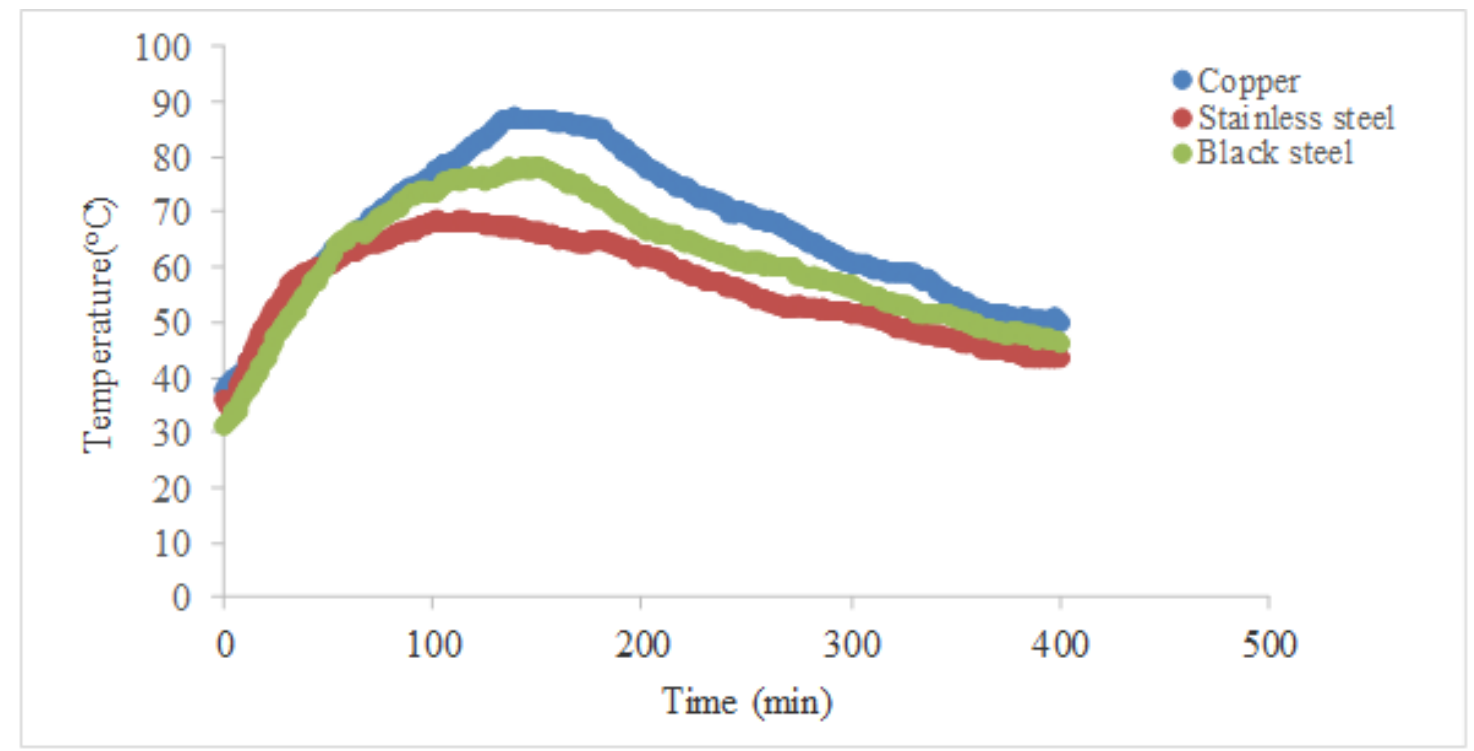

\section{Figure 7: Distribution of Average Drying Temperature in Drying Chamber for Various Types of Heat Exchanger Pipes.}

According to the figure 6 and 7, the copper pipe produces the highest drying temperature compared to black steel and stainless steel pipes. This has the greatest impact on the thermal conductivity of copper compared to black steel and stainless steel. Thermal conductivity is a measure of energy transfer rate [29]. The rate of energy transfer is directly proportional to the drying rate and the higher drying rate is directly proportional to the increase in drying temperature [12].

The heat from the rice husks combustion is used to dry the foodstuffs in drying chamber with heat exchanger pipes. Corn is the foodstuff used for the test sample because of its importance. It is used as processed industrial materials, seeds and animal feed ingredients. In addition, heat exchanger pipes of copper, stainless and black steel are proven to be used as small-scale food drying equipment. This is very much needed by rural communities to run household businesses. This dryer is affordable, easy to operate, and has low operating costs. Furthermore, the drying process takes a short time and does not depend on the weather. Sun drying takes about three days when the weather is clear for a period of 8:00 to 11:30 am in reducing the moisture content of shelled corn from $29 \%$ to $14 \%$ [30]. In addition, rice husk biomass provides good results as a drying energy source. This is in line with [31], that biomass is a reliable source of energy because it can be recycled. Furthermore, it reduces agricultural waste related to rice production. This is because rice is a staple food in many countries, including Indonesia.

\section{CONCLUSIONS}

Furnace modification for rice husks utilization as an energy source is carried out by heat exchanger based on pipe type usage. The pipes used include copper, stainless steel, and black steel as they are proven to be used in the process of converting biomass into thermal energy. The test on a sample of $4 \mathrm{~kg}$ of corn gave optimal temperature results and the average drying temperature in the use of copper, black and stainless steel pipes are $67^{\circ} \mathrm{C}, 61.19^{\circ} \mathrm{C}$, and $56.62^{\circ} \mathrm{C}$, respectively. This energy source for drying rice husks is easy to obtain because it is a byproduct of rice production. Furthermore, this dryer is technically easy to work with, repair and use by the community. 


\section{ACKNOWLEDGEMENTS}

The authors wish to acknowledge DRPM for funding through the 2020 PTUPT research scheme with contract number 1746/UN18.L1/PP/2020 for the second year of research. The author also wishes to thank the Department of Mechanical Engineering, University of Mataram for facilitating the implementation of this research.

\section{REFERENCES}

1. Arora C.P., 2001. Refrigeration and Air Conditioning, Second Edition, Singapore, McGrow Hill.

2. Akonor P.T., Ofori H., Dziedzoave N.T., and Kortei N.K., 2016. Drying Characteristics and Physical and Nutritional Properties of Shrimp Meat as Affected by Different Traditional Drying Techniques, International Journal of Food Science, pp. $1-5$.

3. Manaa S., Younsi M., and Moummi N., 2013. Study of Methods for Drying Dates; Review the Traditional Drying Methods in the Region of Touat Wilaya of Adrar-Algeria, Energy Procedia, 36, pp. 521-524.

4. Susana I.G.B., 2018. Improve of Worker Performance and Quality of Anchovy with Ergonomic Hybrid Solar Dryer, ARPN Journal of Engineering and Applied Sciences, 13(5), pp. 1662-1667.

5. Ochoa-Martinez C.I., Quintero P.T., Ayala A.A., and Ortiz M.J., 2012. Drying Characteristics of Mango Slices Using the Refractance WindowTM Technique, Journal of Food Engineering, 109(1), pp. 69-75.

6. Link J.V., Tribuzi G., and Laurindo J.B., 2017. Improving Quality of Dried Fruits: A Comparison between Conductive Multiflash and Traditional Drying Methods, LWT-Food Science and Technology, 84, pp. 717-725.

7. Incropera F. P., DeWitt D. P., Bergman T., and Lavine A., 2006. Fundamental of Heat and Mass Transfer. Sixth Edition. New York: John Wiley \& Sons.

8. Hamdani, Rizal T.A., and Muhammad Z., 2018. Fabrication and Testing of Hybrid Solar-biomass Dryer for Drying Fish, Case Studies in Thermal Engineering, 12, pp. 489-496.

9. Susana I.G.B., Mara I.M., Okariawan I.D.K., Alit I.B., and Aryadi I.G.A.K.C.A.W., 2019. Ash Hole Variation in Rice Husk Biomass Furnace with Parallel Flow Heat Exchanger to Drying Box Temperature, ARPN Journal of Engineering and Applied Sciences, 14(2), pp 583-586.

10. Yunus Y.M., Al-Kayiem H.H., and Albaharin K.A.K.,2011. Design of a Biomass Burner/Gas-to-gas Heat Exchanger for Thermal Backup of a Solar Dryer, Journal of Applied Science, 11(11), pp 1929-1936.

11. Philippine National Standard, 2015. Agricultural Machinery-Rice Husk Fed Heating System-Specifications, PNS/PAES 264.

12. Susana I.G.B., Alit I.B., and Mara I.M., 2019. Optimization of Corn Drying with Rice Husk Biomass Energy Conversion Through Heat Exchange Drying Devices, International Journal of Mechanical and Production Engineering Research and Development (IJMPERD), 9(5), pp. 1023-1032.

13. Abdulmalek S.H., Assadi M.K., Al-Kayiem H.H., and Gitan A.A., 2018. Effect of Tube Diameter on The Design of Heat Exchanger in Solar Drying System, IOP Conf. Series: Materials Science and Engineering, 328, pp. 1-6.

14. Ejiofor O.S., Prince O., Ogbuefi U., Chinedu O., and Stephen A., 2020. Rice Husk as an Alternative Source of Energy for Green Electricity Generation in Nigeria, Technology Reports of Kansai University (TRKU), 62(2), pp. 45-60.

15. International Renewable Energy Agency, 2017. Renewable Energy Prospects: Indonesia, March. 
16. RUED Provinsi Nusa Tenggara Barat, 2019. Potensi Limbah Perkebunan untuk Biomassa, Peraturan Daerah Provinsi Nusa Tenggara Barat, No. 3.

17. KPMG, 2019. Lombok: Prefeasibility Studies on RE Solutions, Januari.

18. International Finance Corporation, 2017. Converting Biomass to Energy: A Guide for Developers and Investors, Pennsylvania Avenue, N.W. Washington, D.C., June.

19. Awulu J.O., Omale P.A., and Ameh J.A., 2018. Comparative Analysis of Calorific Values of Selected Agricultural Wastes, Nigerian Journal of Technology (NIJOTECH), 37(4), pp. 1141-1146.

20. Quispe I., Navia R., and Kahhat R., 2017. Energy Potential from Rice Husk through Direct Combustion and Fast Pyrolysis: A Review, Waste Management, 59, pp. 200-210.

21. Chokphoemphun S., Eiamsa-ard S., and Promvonge P., 2019. Rice Husk Combustion Characteristics in a Rectangular Fluidized-bed Combustor with Triple Pairs of Chevron-shaped Discrete Ribbed Walls, Case Studies in Thermal Engineering, 14, pp. 1-7.

22. Hung N.V., Quilloy R., and Gummert M., 2018. Improving Energy Efficiency and Developing an Air-Cooled Grate for the Downdraft Rice Husk Furnace, Renewable Energy, 115, pp. 969-977.

23. Yahaya D.B. and Ibrahim T.G., 2012. Development of Rice Husk Briquettes for Use as Fuel, Research Journal in Engineering and Applied Sciences, 1(2), pp. 130-133.

24. Tangka J.K., Ngah J.K., Tidze V.C., and Sako E.T., 2018. A Rice Husk Fired Biomass Stove for Cooking, Water and Space Heating, International Journal of Trend in Research and Development, 5(6), pp. 83-89.

25. Mofijur M., Mahlia T.M.I., Logeswaran J., Anwar M., Silitonga A.S., Ashrafur Rahman S.M., and Shamsuddin A.H., 2019. Potential of Rice Industry Biomass as a Renewable Energy Source, Energies, 12(21), pp. 1-21.

26. Mufid F. and Anis S., 2019. Pengaruh Jenis dan Ukuran Biomassa terhadap Proses Gasifikasi Menggunakan Downdraft Gasifier, Rekayasa Mesin, 10(3), pp. 217-226.

27. Herodian S., 2007. Peluang dan Tantangan Industri Berbasis Hasil Samping Pengolahan Padi, Jurnal Pangan, Vol. 16, No. 1, pp. 38-49.

28. Risdianti D., Murad. G.M.D. Putra, 2016. Kajian pengeringan jahe (zingiber officinale rosc) berdasarkan perubahan geometrik dan warna menggunakan metode image analysis, Jurnal Ilmiah Rekayasa Pertanian dan Biosistem, 4 (2), pp. 275284.

29. Parsonage N.G., 1966. Chapter 6-Thermal Conductivity, The Gaseous State, The Commonwealth and International Library: Chemistry Division, pp. 83-92.

30. Sunarti D. and Turang A., 2017. Penanganan Panen dan Pasca Panen Jagung untuk Tingkat Mutu Jagung, Balai Pengkajian Teknologi Pertanian Sulawesi Utara.

31. Logeswaran J., Shamsuddin A.H., Silitonga A.S., Mahlia T.M.I., 2020. Prospect of using rice straw for power generation: a review, Environmental Science and Pollution Research, 27, pp. 25956-25969. 

